\title{
Lumen
}

Selected Proceedings from the Canadian Society for Eighteenth-Century Studies

\section{Emigration: relocation and dislocation}

\section{Rosena Davison}

Volume 23, 2004

URI : https://id.erudit.org/iderudit/1012193ar

DOI : https://doi.org/10.7202/1012193ar

Aller au sommaire du numéro

Éditeur(s)

Canadian Society for Eighteenth-Century Studies / Société canadienne d'étude du dix-huitième siècle

ISSN

1209-3696 (imprimé)

1927-8284 (numérique)

Découvrir la revue

Citer cet article

Davison, R. (2004). Emigration: relocation and dislocation. Lumen, 23, 179-187. https://doi.org/10.7202/1012193ar

Copyright @ Canadian Society for Eighteenth-Century Studies / Société canadienne d'étude du dix-huitième siècle, 2004
Ce document est protégé par la loi sur le droit d'auteur. L'utilisation des services d'Érudit (y compris la reproduction) est assujettie à sa politique d'utilisation que vous pouvez consulter en ligne.

https://apropos.erudit.org/fr/usagers/politique-dutilisation/ 


\section{Emigration: relocation and dislocation}

\section{Introduction}

Memoirs written by women in exile have a poignancy rarely found in other forms of writing. They recount their feelings of helplessness, suffering and misery in situations not of their own making in which they are obliged to flee to survive or they accompany their fleeing husband or family. The political events which create their predicament are frequently incomprehensible but so serious as to force them to abandon their previous lives, homes and property. The letters written by women who left France during the French Revolution, the émigrées, have an immediacy which arrests our attention by the stark truth of their existence. The memoirs, written often several years after the events described, have great historical value. Both letters and memoirs reflect the particular situation of the author, her skills at adapting to hardship (often, but not always, dictated by her background and upbringing) or her reliance on the help of others. Since most of the émigrées who wrote about their experiences were from the aristocracy, they were united in their condemnation of the ideals of the Revolution and yet remarkably dissimilar in their reaction to their exile. The eloquent account by a duchess of her life as an émigrée was often totally different from that of a marquise, depending on the country chosen as a refuge. Resourcefulness seemed to know no rank. If Mme de La Tour du Pin in exile in Albany, New York, could prepare a lamb for roasting, wielding a huge cleaver and witnessed by none other than Talleyrand, Mme la Marquise de Lage de Volude could survive attacks by pirates and a severe storm during her (unsuccessful) attempt to escape to America. The letters and memoirs of the émigrées offer a rich and varied source of information about a particularly turbulent period of French history. 


\section{Louise-Adélaïde de Condé}

It is well known that one of the largest movements of people during the eighteenth century in France took place as a result of the French Revolution. While it pales in comparison to the deportation of the Huguenots in the previous century, the departure of the émigrés after 1789 does represent a significant population upheaval. Approximately 150,000 French émigrés left France against their will, rather than risk death at the hands of the revolutionaries. Contrary to popular belief, they were not all aristocrats who had been deprived of their property and assumed they would also lose their heads. Some were members of the tiers état, and almost all were under the illusion that their emigration would be of short duration and were unprepared when their money ran out and they were faced with the prospect of a semi-permanent exile. One such émigrée was Louise-Adélaïde de Bourbon-Condé, an exceptional woman whose life would be totally transformed by her decision to leave France. As her name suggests, she was from the highest echelons of French society, a member of the illustrious Condé family, a princess, descendant of Saint Louis and of the Grand Condé, and daughter of Louis Joseph de Condé who, in 1792, organized the counter-revolutionary army known as 'l'armée de Condé'. Her nephew was the duc d'Enghien, kidnapped in Germany and assassinated in 1804 by Napoleon in order to eradicate any hope of a Bourbon restoration. When Louise left France in 1789 she faced twenty-five years of exile which she spent crisscrossing Europe. The events of the Revolution pushed her from Brussels to Turin, from there to Fribourg and then to Vienna. She spent time in Russia, Poland and England, frequently separated from the father and brother to whom she was so attached. Fortunately she was a prolific letter writer and we shall be drawing on her correspondence to familiarize ourselves with her personality and her frame of mind throughout her exile. Her letters describe her many changes of residence, and the anxieties, dangers and hardships related to emigration. In a remarkably frank manner she reveals her reactions to people and places with an endearing and spontaneous sense of humour and a literary style which has been compared to that of Mme de Sévigné.

\section{Emigration and vocation}

Louise de Condé's privileged status in French society in no way prepared her for the life she would lead later; in fact it stood in the way of her true vocation. Part way through her journeys in Europe she took a decision which would totally alter the course of her life: in 1793 in 
Fribourg, where she was to spend two years, she decided to devote her life to God. In her Mémoires spirituels she wrote: 'À Fribourg, je fus frappée [...] émue [...] de la majesté du culte divin [...] Dieu s'empara de mon cœur, il en remplit toute la capacité. Il m'entraîna vers lui comme un torrent de feu' ${ }^{1}$ Her vocation was firm and her decision to divest herself of her title and wealth was based on lengthy reasoning and a full awareness of the difficulties she would face. In 1795, her confessor, convinced of the sincerity of her vocation, finally authorized her to enter a convent. Understandably her family was distraught, her brother, the duc de Bourbon, even accusing her of forgetting him; but her father respected without understanding her decision.

It is tempting to speculate on the origin of her vocation. Orphaned at the age of three, at five she was entrusted to the care of her aunt, the abbesse de Beaumont-les-Tours in Touraine where she would remain for seven years. She then attended the Abbaye de Panthémont, the convent which the daughters of the best families attended. When it came to marriage, Louise was allowed to make her own choice. When circumstances prevented her marriage to the comte d'Artois, she rejected other offers of marriage, rapidly becoming tired of a world she categorized as 'insipide, fou et méchant' or 'un tas de boue couverte d'une gaze d'argent $^{\prime 2}$. In a letter to another princess she wrote: 'Ne vous en déplaise, Madame, l'état de princesse est une sotte chose'. ${ }^{3}$ Louise Condé was known for her good sense and intelligence and so she was fully aware that her chosen direction involved material deprivation at two levels, both as an émigrée and as a nun.

The direction of her journey across Europe was dictated by the advances of Bonaparte's army: travelling with the bare minimum, she left Fribourg for Turin, hurriedly left that city to return briefly to Switzerland before setting off again to Vienna via Munich where she arrived in October 1796. Another return to Switzerland followed, then a long journey to Russia via Bavaria and Warsaw. The assassination of Paul 1st of Russia precipitated her departure from Russia and her return to Warsaw where Louis XVIII had found a temporary home. It was here that Louise took her vows as a 'fille de saint Benoit,' in the presence of

1 M.-L. Jacotey, Louise-Adélaïde de Bourbon-Condé (Langres: Guéniot, 1996), p. 67-68.

2 Jacotey, Louise-Adélaïde de Bourbon-Condé, p. 24.

3 R.P. Dom J. Rabory, Correspondance de la princesse Louise de Condé, fondatrice $d u$ monastère du Temple, lettres écrites pendant l'émigration à sa famille et à divers (Paris: Retaux-Bray, 1889), $x$. 
her father, who declared that his daughter ' $n$ 'a jamais autant couru le monde que depuis qu'elle veut y renoncer' ${ }^{4}$ Overcome by a feeling of isolation and surrounding hostility she decided to leave Warsaw to join her father in England, accompanied by Mme de la Rozière or Sister Sainte Rose and by Eléonore, a young Polish girl abandoned by her parents at the door of a Russian convent and adopted by Louise. In exchange for the exorbitant sum of 60 louis, the captain of a boat leaving for England agreed to let them have his cabin. They arrived at Gravesend where she was welcomed like a princess, the king having dispatched William Pitt and Lord Moira to offer her the respects of the royal family.

She was to spend several years in England, not, unfortunately, all at the same address, but comforted by the proximity of her father and brother. After a separation of nine years she felt it wise to warn them in advance of how much she had changed. This is the unflattering portrait of herself she sent from Dantzig: 'La déesse blanche à la face rouge n'existe plus. Un visage allongé, jaune, ridé à force de larmes, les yeux battus jusqu'à la moitié des joues et abîmés par les larmes qu'ils ont eu tant de sujets de verser; en un mot, soixante ans et à faire peur; voilà mon portrait et il n'est pas chargé. [She was in fact 48]. Au surplus, n'en accusez pas les austérités dont vous m'avez parlé plus d'une fois. Ce sont celles du cœur qui ont été terribles, et vous croirez facilement que la dernière année a mis le sceau à l'article des souffrances' ${ }^{\prime}{ }^{5}$ Now in a protestant country, she decided to follow her father's advice and wear a simple black veil on her head instead of the full nun's costume.

Following a very brief stay with her father at Wanstead House in London, the three travellers headed for Bodney Hall in the county of Norfolk where Mme de Lévis-Mirepoix, leader of a convent of French Benedictine nuns had placed a small cottage at her disposal. From there and from a second convent, Old Heath Hall near Wakefield in Yorkshire, Louise sent a series of letters, now in the Archives nationales in Paris, in which she wrote of her principal preoccupations such as her business affairs, her health, and important events both personal and political. Alongside comments on the devastation wreaked by Napoleon's army, or on the fate of the royal families of Europe, she slipped into the letters she sent to her brother or to $\mathrm{M}$. Contye, who looked after her business affairs, requests for items to make their daily existence more pleasant. These included chocolate, dress material for Eléonore, pastilles à la

4 Quoted by Jacotey, p. 92.

5 Rabory, p. 274. 
menthe, tobacco or snuff, and wine. She followed with avid interest the politics of her time, showing a strong degree of scepticism. She recounts to her father and brother the difficulties of convent life, the state of religion in France, but never loses her sense of humour. Some of these letters surprise us, as we shall see, since they reveal a personality which on the surface would appear incompatible with her vocation, but are always characterized by sincerity and forthrightness. For example, in this letter to her brother we see an indication of how disagreeable and taxing life at Bodney Hall could be: 'J'ai près de cent ans à ce qu'il me semble et vous êtes mon aîné de dix-huit mois [...] Je me crois l'aînée de tout l'univers par le gothique de mes idées et de mes sentiments sur tout ce qui se voit en ce bas monde. ${ }^{6}$ On the political front, she insisted on remaining up to date on the events which were happening throughout Europe, and made several astute and forthright comments in her letters. When, after the battle of Austerlitz, Napoleon obliged Francis II to abandon the title of emperor, she wrote to her father:

Voilà donc François II "désimpératorisé". Il n'est même pas dit qu'il garde toujours ce qu'il croit avoir encore. Au surplus tout ceci est bien mérité et quand on a vogué à force de ramer dans l'eau bourbeuse de la lâcheté, il est assez naturel de ne trouver d'autre port qu'un abîme de fange où l'on reste enfoncé.

It is not surprising that Louis XVIII wrote of her: 'La Princesse Louise écrit mieux, elle raisonne mieux qu'aucune femme de France. ${ }^{8}$ Louise often expresses her outrage at the moral decadence of her epoch. On learning of Bonaparte's divorce and remarriage with a sister of the emperor Alexander (she always referred to him in her letters as Buona Parte or simply BP), her cynicism knew no bounds: 'On dit que B.P. va divorcer et épouser une sœur de l'Empereur Alexandre; jen'en serais pas surprise, car il doit désirer de dignes successeurs de ses hautes destinées. ${ }^{\prime}$ ' $\mathrm{L}$ 'immoralité,' she wrote to her brother on March 20 1810, 'est générale et se retrouve dans les mœurs; l'honneur, la probité [...] L'humanité [...] se livre tout entière à ses passions, à l'égoïsme le plus absolu et au total oubli de Dieu, ce qui conduit de précipice en précipice'. ${ }^{10}$

6 Quoted by Jacotey, p. 98.

7 Jacotey, p. 98.

8 Jacotey, p. 98.

9 Letter to her father dated December 28, 1807. Archives nationales de Paris AP/34/2.

10 Jacotey, p. 99. 


\section{Difficulties in England}

Life at Bodney Hall was not going well. She complained of health problems which she felt were associated with her lodging or 'taudis sans feu' ${ }^{\prime 11}$ as she called it. To M. Contye she wrote 'Je ne me porte pas bien, ni Mme de la Rozière non plus; de vous à moi nous sommes bien gauchement soignées, horriblement logées [...] des vents à tout renverser [...] un petit foyer comme un réchaud, où depuis 3 semaines nous ne faisons plus de feu à cause du tourment de la fumée [...] une humidité horrible, plein nord. ${ }^{12}$ We learn from the abbé Baston, also exiled in England, that Bodney Hall was 'un chateau antique et vaste' which had been lent free of charge to the nuns by its rich Anglican owner whose appointment as an ambassador obliged him to spend his time abroad. Its isolation was somewhat attenuated by the kindness of distant neighbours who had heard of the nuns' courage in the face of misfortune and persecution. ${ }^{13}$

As an émigrée Louise felt she was mistrusted and in spite of her generosity to the convent, the pension she paid to the convent was considered too modest (she had had to leave her dowry in Warsaw) and her life was made unbearable. In her letters she made light of it, writing: 'Les Princesses ne sont plus de mode et surtout celles de la maison de Bourbon qui ne peuvent plus jetter tout par les fenêtres. [...] Vous ne pouvez vous imaginer ce que je souffre ici [...] Les peines d'ici deviennent intolérables' ${ }^{14}$ 'Je suis regardée ici comme payant la moindre des pensions, comme étant presque à la charge et charité de la maison parce que je ne lui rends aucun service. ${ }^{15}$ It was definitely time to move on. Her dream was to found her own religious community: as she wrote to her father who initially was willing to support her financially in this project, she wished to 'se retirer dans un lieu solitaire et y rassembler quelques personnes du même état pour y vivre loin de tout rapport avec le monde. ${ }^{16}$ She made several attempts to find an appropriate house for the community, all in places well removed from the London area. A trip to a potential location for the community in Wakefield, Yorkshire disap-

11 Letter dated March 12, 1806 to M. Contye. Archives nationales.

12 Letter dated March 2, 1809 to M. Contye. Archives nationales.

13 Mémoires de l'abbé Baston, Chanoine de Rouen (Paris: Picard, 1897-99), 2: p. 46.

14 Letter dated November 15, 1808 to her brother. Archives nationales.

15 Jacotey, p. 99.

16 Letter dated June 29, 1808 to her father. Archives nationales AP/34/2. 
pointed her: in spite of its beautiful location, too many staircases were not appropriate for her: 'La promenade est agréable pour les bonnes jambes mais pour moi il faut me contenter de la vue qu' on y découvre qui est des plus belles; monter et descendre, $c^{\prime}$ est continuel [...] jugez du charme pour chère sœur vielle et infirme ${ }^{\prime} .{ }^{17}$ On her return she moved to Heath, near Norwich, where the community had been obliged to relocate. In her letters she constantly expressed her regret at not being closer to her brother: 'Pourquoi pour vous embrasser faut-il que ce soit à travers un espace de 90 milles, et encore par des brouillards, qui rendent le voile de séparation cent fois plus épaisse! ${ }^{\prime 18}$

\section{Return to France}

The failure to set up her own religious community, the fall of Napoleon and the return of her father and brother to Paris, as well as the restoration of Louis XVIII were good reasons for Louise to contemplate leaving England. But in a letter to a M. Prévot she reveals her pessimism about the future of Europe: 'J'ai bien la persuasion que l'orage va fondre sur Buona Parte et qu'il est possible qu'il y succombe mais je n'ai pas celle du rétablissement des Bourbons; il s'en faut de beaucoup et je crains fort de nouveaux troubles seulement, par des factions républicaines et d'autres orléanistes. ${ }^{19}$ Another letter shows her scepticism about the future of the new regime: 'Il y a longtemps que je crois que la Maison de Bourbon finit comme tant d'autres ont fini [...] Dans la nouvelle France tout n'est-il pas changé jusqu'à l'argent? Tout sera pour moi la Chine. ${ }^{20}$ Finally Louise agreed to leave Heath and return to Paris where her first priority was to establish a home for her order. However, Louise's premonitions proved correct: at the news of Napoleon's imminent return to Paris, the king left suddenly. Louise also departed, just in time, the sound of the cannons welcoming the Emperor back was ringing in her ears. Now, during the Hundred Days, she waited in England, in poor spirits and health. After a further fourteen months of exile she was able to return to Paris where she would supervise the renovations to the semi-ruined Temple. The dungeon had been razed to the ground, leaving the gar-

18 Letter dated 25 January, 1811. Archives nationales.

19 Letter dated September 15, 1805. Archives nationales.

20 Jacotey, p. 101-2. 
dens, part of the Palais du Grand Prieur and the room where Louis XVI had been held prisoner before being led to the guillotine. Louis XVIII had granted her this as a permanent home where she could establish her community or maison de l'Adoration perpétuelle. In restoring the catholic hierarchy in France, the Concordat accepted only the re-establishment of those religious orders known as hospitaliers which offered help to travellers, to pilgrims or to the sick, or which were devoted to education.

At the age of sixty Louise de Condé, alias sœur Marie-Joseph de la Miséricorde, the name she had adopted on first leaving England, was finally able to settle down to complete her life's work. The renovations were proceeding much more slowly than expected but eventually it was ready and she was able to welcome her community and the young girls she would train. Far from slowing down, and in spite of her poor health, her days were now fuller than ever: at last she could devote herself entirely to her calling, encouraging the novices to lead an active life which involved exercise in the open air, and teaching them to behave in a way which reflected the modesty and gravity of their condition while allowing them the freedom to express their character and age. She willingly opened her doors to English girls, in a gesture of gratitude to the country which had welcomed so many émigrés. In addition to teaching, devotional practices, and the administration of the convent, she found time to write short religious treatises and prayers. The closing years of her life were rich and meaningful but too brief. She died in March 1824 at the age of 67 . A fitting tribute to her was made by Lord Jerningham who wrote: 'De toutes les personnes de la famille royale, la seule vraiment heureuse est la princesse Louise la nonne, qui semble en parfait contentement. $^{21}$

\section{Conclusion}

The letters of Louise de Condé are in many ways surprising. They reveal a woman who responded eagerly to a strong calling to serve God in spite of the circumstances of her family and her emigration, both of which might have conspired to discourage her, and in spite of the opposition of her beloved brother. Her correspondence permits the reader to participate in the hardships she suffered on her journeys outside of France even though, while forthright in her criticism of what displeased her, she

21 Pierre de Ségur, La Dernière des Condé (Paris: Calmann Lévy, 1899), p. 163. 
generally avoided expressions of self-pity. The style of the letters is not that of a great literary writer; yet they express very directly, often humorously, her opinions of the political events which were unfolding in Europe and the predicaments she faced during her emigration, offering the reader a very specific and fascinating view of the life of an émigrée set in the context of a Europe of shifting boundaries and alliances.

ROSENA DAVISON

Simon Fraser University 